JURNAL NOMINAL / VOLUME VI NOMOR 2 / TAHUN 2017

\title{
PENGARUH SUSTAINABILITY REPORTING, PERTUMBUHAN PERUSAHAAN, DAN GOOD CORPORATE GOVERNANCE TERHADAP PENGUNGKAPAN AUDIT GOING CONCERN
}

\author{
Muhammad Nur Aditya \\ Prodi Akuntansi S1 Universitas Negeri Yogyakarta \\ mnahdietya@gmail.com
}

\begin{abstract}
Abstrak: Pengaruh Sustainability Reporting, Pertumbuhan Perusahaan, dan Good Corporate Governance terhadap Pengungkapan Audit Going Concern. Penelitian ini bertujuan untuk mengetahui pengaruh sustainability reporting, pertumbuhan perusahaan, dan good corporate governance terhadap pengungkapan opini going concern. Penelitian ini menggunakan metode kuantitatif - kausal komparatif dengan mengambil informasi dari data sekunder melalui laman Bursa Efek Indoensia. Populasi penelitian meliputi 44 perusahaan perbankan yang terdaftar di Bursa Efek Indonesia tahun 2011 - 2015. Dari 44 perusahaan tersebut, diambil 29 sampel dengan jumlah observasi sebanyak 145 perusahaan menggunakan metode purposive sampling. Pengujian hipotesis menggunakan program komputer pengolah data dengan analisis regresi logistik. Hasil penelitian menunjukkan bahwa Aspek Lingkungan, Aspek Sosial, Pertumbuhan Perusahaan, Komisaris Independen dan Komite Aduti tidak berpengaruh pada pengungkapan opini going concern, sedangkan Aspek Ekonomi dan Kepemilikan Institusional mempunyai pengaruh pada pengungkapan opini going concern.
\end{abstract}

Kata kunci: opini going concern, sustainability reporting, pertumbuhan perusahaan, good corporate governance.

Abstract: The Influence of Sustainability Reporting, Company's Growth, and Good Corporate Governance on Going Concern Audit Disclosure. This research aims to examine the influence of sustainability reporting, company's growth, and good corporate governance towards giving of going concern opinion. This research are based on quantitative method and comparative-cause approach. The data was taken from financial statements of banking company listed in Indonesia Stock Exchange in the period 2011 -2015. The population of this research are 44 companies and selected to be 29 companies with 145 observation data obtained by purposive sampling. The logistic regression used to examine the hypothesis. The results of the study are, Environment Aspect, Social Aspect, Company's Growth, Independence Commissioner and Audit Committee have no effect with the disclosure of going concern opinion, otherwise Economic Aspect and Institutional Ownership have significant effect with the disclosure of going concern opinion.

Keywords: going concern opinion, sustainability reporting, company's growth, good corporate governance.

\section{PENDAHULUAN}

Setiap usaha didirikan untuk tetap terjaga kelangsungan usahanya (going concern). Informasi mengenai kelangsungan usaha penting terutama ketika kondisi keuangan tidak pasti, dan stakeholder mengharapkan adanya early warning akan kegagalan perusahaan, dan hal tersebut merupakan tanggung jawab seorang auditor, karena auditor merupakan pihak yang menjembatani kepentingan pihak principal dan agent. Opini auditor yang berkualitas akan menuntut pada pengambilan keputusan yang lebih baik. Pemberian status going concern bukan tugas yang mudah, karena seringkali timbul masalah dalam diri auditor, beberapa penyebabnya antara lain: 1) Masalah self- 


\section{JURNAL NOMINAL / VOLUME VI NOMOR 2 / TAHUN 2017}

fulfilling prophecy, dimana ketika auditor memberi opini going concern maka perusahaan akan bangkrut, karena investor dan kreditor yang menarik dana, 2) Tidak terdapat prosedur yang tetap dalam menetapkan opini going concern. Oleh karena itu, masih terdapat perusahaan yang tidak sehat menerima opini WTP. Beberapa pertimbangan yang digunakan auditor dalam memberikan opini going concern adalah sustainability reporting, pertumbuhan perusahaan, dan good corporate governance ((Sutedja, 2010; Sihombing., et al 2014; Setyarno., et al 2006; Rahman dan Siregar, 2012; Rudyawan dan Badera, 2009; Widyantari, 2011; Santosa dan Wedari, 2007; Fitri dan Satyawan, 2014).

Sustainability reporting merupakan sebuah paradigma baru dimana sebelumnya usaha yang hanya berorientasi single $P$ (Profit) menjadi Triple P (Profit, Planet, People). Tujuan dari sustainability reporting adalah untuk tercapainya sustainable development (KPMG, 2008). Sustainability reporting harus menjadi bagian dari strategi perusahaan untuk menciptakan keunggulan bersaing (Porter dan Kramer, 2006) karena terbukti bahwa sustainability reporting berkorelasi positif pada kinerja keuangan (Weber, Koellner, Habegger, Steffensen dan Ohnemus, 2008). Sustainability reporting muncul semenjak adanya berbagai tragedy kemanusiaan dan lingkungan di dunia seperti Minamata,
Chernobyl, dan Lumpur Lapindo. Di Indonesia undang-undang yang mengatur mengenai sustainability reporting adalah UU PT. No. 40/2007 BAB IV (Pasal 66 ayat $2 \mathrm{~b} \& 2 \mathrm{c}$ ) dan BAB V Pasal 74 ayat 1 \& 2, serta peraturan Bapepam LK No. X.K.6, dimana perusahaan wajib melaporkan pelaksanaan tanggung jawab sosial serta lingkungan. Namun, jumlah perusahaan yang menerbitkan sustainability report di Indonesia masih sedikit dibanding negara maju (Meryana, 2013). Di dalam sustainability reporting terdapat tiga konsep utama yaitu: aspek lingkungan, aspek ekonomi dan aspek sosial, yang mana ketiganya merupakan konsep Triple Bottom Line Sustainability Reporting.

Aspek lingkungan meliputi berbagai aktivitas perusahaan seperti dampak aktivitas organisasi pada lingkungan. Aktivitas perusahaan berkaitan dengan lingkungan kini menjadi sebuah sorotan. Perusahaan yang bertanggung jawab pada lingkungan artinya sadar bahwa lingkungan perlu dijaga kesinambungannya, sehingga stakeholder akan percaya pada perusahaan, serta yakin akan kelangsungan usaha perusahaan, karena perusahaan tidak akan terganggu akibat operasional yang tidak bertanggung jawab pada lingkungan.

\section{H1: Aspek lingkungan berpengaruh negatif pada pengungkapan opini going concern.}




\section{JURNAL NOMINAL / VOLUME VI NOMOR 2 / TAHUN 2017}

Aspek ekonomi berkaitan dengan dampak ekonomi perusahaan pada stakeholder dan sistem ekonomi dalam lingkup lokal, nasional, maupun global. Perusahaan sebagai institusi sosial harus menunjukkan kontribusi ekonomi pada masyarakat luas, sehingga tercipta nilai tambah untuk perusahaan, salah satunya adalah kelangsungan usaha yang terjaga dengan baik.

\section{H2: Aspek ekonomi berpengaruh negatif} pada pengungkapan opini going concern.

Aspek sosial berkaitan dengan aktivitas sosial perusahaan pada stakeholder terutama untuk karyawan, masyarakat dan negara, dan konsumen. Perusahaan yang peduli pada stakeholdernya maka loyalitas dari para stakeholder akan terjaga dengan baik, sehingga akan meminimalkan konflik antara perusahaan dengan pihak-pihak yang berhubungan, dan kelangsungan usahanya akan lebih baik.

\section{H3: Aspek sosial berpengaruh negatif} pada pengungkapan opini going concern.

Pertumbuhan perusahaan menunjukkan kemampuan perusahaan dalam mempertahankan kelangsungan usahanya (Sutedja, 2010). Perusahaan dengan negative growth mengindikasikan penurunan kinerja yang mengarah ke kebangkrutan, yang mana kebangkrutan merupakan indikator auditor untuk memberi opini going concern (Rahman dan Siregar, 2012; Petronila, 2004). Hasil penelitian mengenai pertumbuhan perusahaan pada opini going concern antara lain, penelitian Petronila (2004) dan Rahman dan Siregar (2012) menyatakan bahwa pertumbuhan perusahaan berpengaruh pada pengungkapan opini going concern, sedangkan Setyarno et al., (2006), Widyantari (2011), Sutedja (2010), Rudyawan dan Badera (2009), serta Santosa dan Wedari (2007) menyatakan bahwa pertumbuhan perusahaan tidak berpengaruh pada pengungkapan opini going concern.

\section{H4: Pertumbuhan perusahaan berpengaruh negatif pada} pengungkapan opini going concern.

Good corporate governance erat kaitannya dengan going concern problems. Corporate governance yang buruk menandakan bahwa perusahaan tidak dijalankan dengan baik, sehingga kinerjanya pun buruk (Iskandar et al., 2011). Pelaksanaan GCG yang buruk mengakibatkan tingginya risiko investasi, karena kinerja perusahaan yang buruk. Prinsip good corporate governance mulai menjadi perbincangan hangat semenjak munculnya kasus mengenai tata kelola perusahaan, seperti Enron, (Li, 2010, Pavel dan Encontro, 2012), manipulasi laporan keuangan Bank Lippo, kasus Bank Century (Suhardjanto, 2012). Masalah going concern yang ada dapat diatasi dengan tata 


\section{JURNAL NOMINAL / VOLUME VI NOMOR 2 / TAHUN 2017}

kelola perusahaan yang baik (Sihombing et al., 2014). Di Indonesia penerapan good corporate governance masih lemah, dibuktikan dari survei yang dilakukan AGGA-CLSA Asian Pacific Markets mengenai penerapan GCG di 11 negara Asia Pasifik, dimana Indonesia di tahun 2016 menduduki peringkat terendah.

Tabel 1. Corporate Governance Scores in Asia (2016)

\begin{tabular}{|c|c|c|c|c|c|c|}
\hline$\sqrt{2}$ & हే & 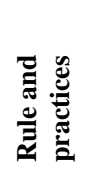 & 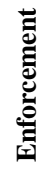 & : & 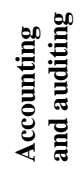 & ט己 \\
\hline Singapore & 67 & 63 & 63 & 67 & 87 & 55 \\
\hline Hongkong & 65 & 63 & 69 & 69 & 70 & 53 \\
\hline Japan & 63 & 51 & 63 & 69 & 75 & 58 \\
\hline Taiwan & 60 & 54 & 54 & 64 & 77 & 50 \\
\hline Thailan & 58 & 64 & 51 & 45 & 77 & 50 \\
\hline Malaysia & 56 & 54 & 54 & 48 & 82 & 42 \\
\hline India & 55 & 59 & 51 & 56 & 58 & 49 \\
\hline Korea & 52 & 48 & 50 & 50 & 53 & 70 \\
\hline China & 43 & 38 & 40 & 40 & 36 & 67 \\
\hline Philippines & 38 & 35 & 19 & 19 & 41 & 65 \\
\hline Indonesia & 36 & 35 & 21 & 21 & 33 & 58 \\
\hline
\end{tabular}

Sumber: CLSA Asia-Pacific Markets, Asian Corporate Governance Association (2016)

Good corporate governance dapat diukur menggunakan 3 indikator yaitu: kepemilikan institusional, Komisaris Independen, dan Komite Audit.

Kepemilikan institusional merupakan proporsi saham biasa yang dimiliki oleh institusi. Dengan adanya kepemilikan institusional maka akan mampu mengawasi perusahaan dengan baik, serta meminimalisir kecurangan yang dilakukan manajemen.

\section{H5: Kepemilikan institusional} berpengaruh negatif pada pengungkapan opini going concern.
Komisaris Independen merupakan anggota dewan komisaris yang tidak memiliki afiliasi dengan manajemen, dan bebas dari segala bentuk urusan yang mampu menganggu independensinya. Melalui adanya Komirsaris Independen maka akan tercipta keseimbangan keputusan antara manajemen dan stakeholder, sehingga akan meminimalkan konflik yang dapat mempengaruhi kelangsungan usaha perusahaan.

\section{H6: Komisaris Independen berpengaruh negatif pada pengungkapan opini going concern.}

Komite Audit merupakan komite yang dibentuk Dewan Komisaris untuk membantu kinerjanya terutama dalam pelaporan keuangan, audit internal, dan dukungan pada audit eksternal. Perusahaan yang memiliki Komite Audit memiliki operasional yang lebih transparan dan pengawasan yang lebih baik, dimana hal tersebut menjaga kesinambungan perusahaan.

H7: Komite Audit berpengaruh negatif pada pengungkapan opini going concern.

\section{METODE PENELITIAN}

\section{Jenis Penelitian}

Penelitian ini merupakan penelitian kausal komparatif dengan pendekatan kuantitatif. Penelitian kausal komparatif berusaha mencari adanya hubungan sebab akibat antarvariabel yang diamati dengan mengidentifikasi akibat terlebih dahulu 


\section{JURNAL NOMINAL / VOLUME VI NOMOR 2 / TAHUN 2017}

kemudian baru dipelajari sebabnya. Sedangkan, pendekatan kuantitatif digunakan karena penelitian ini menggunakan statistik yang mengolah data angka menjadi informasi.

\section{Waktu dan Tempat Penelitian}

Penelitian dilakukan dengan mengambil data di laman Bursa Efek Indonesia (www.idx.co.id) dan Indonesia Capital Market Electronic Library (eCamel). Data yang diambil adalah laporan keuangan perusahaan subsektor perbankan pada tahun 2011-2015. Waktu penelitian adalah saat pengumpulan dan analisis data. Penelitian dilakukan pada Januari hingga Februari 2017.

\section{Populasi dan Sampel}

Populasi penelitian mencakup sekuruh perusahaan subsektor perbankan yang terdaftar di BEI sebanyak 44 perusahaan. dengan teknik purposive sampling, diambil 29 perusahaan periode 2011 - 2015 sehinggda didapat 145 observasi. Kriteria pengambilan sampel adalah perusahaan subsektor perbankan yang melakukan IPO sebelum tahun 2011 dan memuat semua informasi yang dibutuhkan dalam penelitian ini.

\section{Definisi Operasional Variabel}

Dalam penelitian ini terdapat satu variabel dependen, dan tiga variabel independen. Variabel dependen yaitu going concern diukur dengan variabel dummy, dimana skor 1 diberikan bagi perusahaan yang menerima opini going concern dan nilai 0 untuk yang non going concern. Variabel independen dalam penelitian ini adalah sustainability reporting, pertumbuhan perusahaan, dan good corporate governance. Sustainability reporting berkaitan dengan pengungkapan informasi sosial dan lingkungan, selain sisi profit, sehingga kepercayaan dari stakeholder akan meningkat, dan hal itu berdampak pada kelangsungan usaha perusahaan yang makin baik. Sustainability reporting diukur menggunakan indikator sustainability reporting dari GRI disesuaikan dengan operasional perbankan. Tabel 2. Indikator Sustainability Reporting

\begin{tabular}{|c|c|}
\hline Aspek & Sub Indikator \\
\hline \multirow[t]{3}{*}{ Lingkungan } & $\begin{array}{l}\text { Strategi dan } \\
\text { lingkungan }\end{array}$ \\
\hline & $\begin{array}{l}\text { Pemakaian dan } \\
\text { pengehamatan bahan dan } \\
\text { energi }\end{array}$ \\
\hline & $\begin{array}{l}\text { Upaya mitigasi dampak } \\
\text { lingkungan produk dan } \\
\text { layanan }\end{array}$ \\
\hline \multirow[t]{4}{*}{ Ekonomi } & $\begin{array}{l}\text { Pengungkapan } \\
\text { pendekatan manajemen }\end{array}$ \\
\hline & $\begin{array}{lr}\text { Nilai ekonomi yang } \\
\text { diterima } \\
\text { didistribusikan }\end{array}$ \\
\hline & Imbalan pasca kerja, dan \\
\hline & $\begin{array}{l}\text { Dampak ekonomi tidak } \\
\text { langsung }\end{array}$ \\
\hline \multirow[t]{5}{*}{ Sosial } & Kesehatan dan keamanan \\
\hline & Pelatihan dan pendidikan \\
\hline & $\begin{array}{l}\text { HAM dan non } \\
\text { diskriminasi }\end{array}$ \\
\hline & $\begin{array}{l}\text { Tanggung jawab sosial } \\
\text { masyarakat }\end{array}$ \\
\hline & Tanggung jawab produk \\
\hline
\end{tabular}

Sumber: Data diolah (2017) 


\section{JURNAL NOMINAL / VOLUME VI NOMOR 2 / TAHUN 2017}

Perhitungan variabel sustainability reporting menggunakan variabel dummy, kemudian dihitung dengan formula:

$$
S R D I=\frac{n}{k}
$$

Keterangan:

$$
\begin{array}{lll}
\text { SRDI }: & \text { Sustainability Report } \\
& \text { Disclosure Index perusahaan } \\
\mathrm{n} & : \text { Jumlah item yang } \\
& \text { diungkapkan perusahaan } \\
\mathrm{k} \quad: & \text { Jumlah item yang diharapkan }
\end{array}
$$

Pertumbuhan perusahaan adalah kemampuan perusahaan dalam mempertahankan kelangsungan usahannya. Pertumbuhan perusahaan diukur dengan pertumbuhan laba bersih. rumus perhitungannya adalah:

$$
\begin{aligned}
& \begin{array}{l}
\text { Pertumbuhan Laba Bersih } \\
=\frac{\text { Laba Bersih }}{t}-\text { Laba Bersih } \\
\text { Laba Bersih } \\
\text { Good corporate governance }
\end{array}
\end{aligned}
$$

merupakan mekanisme dalam menjalankan perusahaan secara efektif dan efisien agar tujuan dapat dicapai sesuai rencana. Good corporate governance diukur dengan kepemilikan institusional, Komisaris Independen, dan Komite Audit.

$G C=\alpha+\beta_{1}$ Ins $_{O w n}+\beta_{2}$ Ind $_{\text {Comm }}+\beta_{3}$ Komite $+\varepsilon$

Keterangan:
GC : Opini going concern yang diberi nilai 1, dan non going concern yang diberi nilai 0

$\alpha \quad$ : Konstanta

$\beta_{1-3} \quad:$ Koefisien regresi logistic

Ins own $_{\text {: Proporsi saham biasa yang }}$ dipegang oleh lembaga

$$
\begin{aligned}
\text { Ind }_{\text {comm }}: & \text { Presentasi } \\
& \text { Independen dalam total } \\
& \text { dewan komisaris }
\end{aligned}
$$

Komite : Jumlah Komite Audit dalam perusahaan

$\varepsilon \quad:$ Kesalahan residual

\section{Teknik Pengumpulan Data}

Pengumpulan data dilakukan dengan metode observasi nonpartisipan, yaitu peneliti hanya berperan mengamati dan mengumpulkan data tanpa berperan serta di dalamnya. Data yang digunakan adalah data sekunder yaitu laporan keuangan yang dipublikasikan di laman Bursa Efek Indonesia.

\section{Teknik Analisis Data}

Teknik analisis data dalam penelitian ini menggunakan analisis statistik deskriptif dan analisi regresi logistik. Analisis statistik deskriptif digunakan untuk mendeskripsikan semua data yang telah terkumpul untuk menjabarkan nilai maksimum, minimum, rata-rata, standar deviasi, serta distribusi frekuensi pada pengukuran variabel. Sedangkan, analisis regresi logistik digunakan untuk menguji apakah probabilitas terjadinya variabel 


\section{JURNAL NOMINAL / VOLUME VI NOMOR 2 / TAHUN 2017}

terikat dapat diprediksi dengan variabel bebasnya. Analisis ini digunakan karena adanya variabel yang digunakan merupakan campuran antara variabel metrik dan nonmetrik. Berikut adalah tahapan analisis regresi logistik:

\section{Menilai Kelayakan Model Regresi}

Kelayakan model regresi dinilaidengan menggunakan Hosmer and Lemeshow's Goodness of Fit Test. Uji ini digunakan untuk melihat kesesuaian antara data dengan model. Jika hasil uji Hosmer and Lemeshow's Goodness of Fit Test lebih dari 0,05 maka model dikatakan sesuai, namun jika kurang dari 0,05 berarti model tidak sesuai.

\section{Menilai Keseluruhan Model Fit}

Uji ini digunakan untuk menilai kesesuaian model yang telah dihipotesiskan dengan data. Output pengolah data statistik memberikan dua nilai $-2 \log L$ yaitu satu untuk model yang hanya memasukkan konstanta saja dan satu model dengan konstanta serta tambahan variabel bebas. Pengurangan nilai antara $-2 \log L$ awal dengan nilai $-2 \log L$ pada langkah berikutnya menunjukkan bahwa model yang dihipotesiskan fit dengan data.

\section{Koefisien Determinasi}

Nilai Nagelkerke $R \quad \begin{array}{r}\text { square } \\ \text { menunjukkan variabilitas }\end{array}$
variabel
variabilitas variabel independen, sedangkan
sisanya dijelaskan oleh variabel lain di luar
model penelitian.




\section{JURNAL NOMINAL / VOLUME VI NOMOR 2 / TAHUN 2017}

\section{HASIL \\ PENELITIAN \\ DAN}

\section{PEMBAHASAN}

\section{Statistik Deskriptif}

Analisis statistik deskriptif digunakan untuk mendeskripsikan data untuk menjabarkan nilai minimal, maksimal, rata-rata, standar deviasi dan distribusi data. Berikut adalah hasil analisis deskriptif dalam penelitian ini:

Tabel 3. Statistik Deskriptif 1

\begin{tabular}{lrrrr}
\hline & Min & \multicolumn{1}{c}{ Max } & Mean & Std. Dev \\
\hline GoingConcern & 0 & 1 &, 11 &, 314 \\
Env & 0 & 3 & 1,37 & 1,26 \\
Eco &, 67 & 2,00 & 1,29 &, 589 \\
Soc & 1 & 5 & 3,55 & 1,34 \\
Growth & $-79,87$ & 35,20 &,- 271 & 7,36 \\
InsOwn &, 11 & 1,00 &, 726 &, 23 \\
ComInd &, 33 & 1,00 &, 58 &, 10 \\
ComAud & 2 & 8 & 3,89 & 1,21 \\
\hline
\end{tabular}

Sumber:Data diolah (2017)

Tabel 4. Statistik Deskriptif 2

\begin{tabular}{|c|c|c|c|c|c|c|}
\hline & \multicolumn{2}{|c|}{ Min } & \multicolumn{2}{|c|}{ Max } & \multicolumn{2}{|c|}{ Mean } \\
\hline & U & $\begin{array}{l}\text { U } \\
Z\end{array}$ & O & $\begin{array}{l}U \\
\mathrm{Z} \\
\mathrm{Z}\end{array}$ & O & Oঠ \\
\hline GC & 1 & 0 & 1 & 0 & 1,00 & ,00 \\
\hline Env & 0 & 0 & 3 & 3 & 1,44 & 1,36 \\
\hline Eco & ,67 & ,67 & 1,67 & 2,00 & 1,04 & 1,33 \\
\hline Soc & 2 & 1 & 5 & 5 & 3,75 & 3,53 \\
\hline \multirow[t]{3}{*}{ Growth } & $-8,8$ & $-79,87$ & 1,15 & 35,2 &,- 73 &,- 21 \\
\hline & \multicolumn{2}{|c|}{ Min } & \multicolumn{2}{|c|}{ Max } & \multicolumn{2}{|c|}{ Mean } \\
\hline & O & $\begin{array}{l}\text { U } \\
Z\end{array}$ & O & $\begin{array}{l}\text { U } \\
\text { Z }\end{array}$ & U & $\begin{array}{l}\text { U } \\
\text { Z }\end{array}$ \\
\hline InsOwn &, 51 & ,11 & 1,00 & ,99 &, 86 & ,79 \\
\hline ComInd &, 33 &, 33 &, 75 & 1,00 &, 57 &, 58 \\
\hline ComAud & 3 & 2 & 6 & 8 & 3,75 & 3,91 \\
\hline
\end{tabular}

Sumber: Data diolah (2017)

Hasil analisis untuk variabel going concern menunjukkan nilai rata-rata $0,11<$ 0,5 sehingga menunjukkan bahwa opini going concern dengan kode 1 lebih sedikit muncul dari 145 observasi penelitian.

Tabel 5. Distribusi Opini Going Concern

\begin{tabular}{rrrrr}
\hline & & Frequency & \multicolumn{1}{c}{$\%$} & \multicolumn{1}{c}{ Valid (\%) } \\
\hline \multirow{3}{*}{ Valid } & 0 & 129 & 89,0 & 89,0 \\
\cline { 2 - 5 } & 1 & 16 & 11,0 & 11,0 \\
\cline { 2 - 5 } & Total & 145 & 100,0 & 100,0 \\
\hline
\end{tabular}

Sumber: Data diolah (2017)

Berdasarkan tabel 3, dari 145 observasi penelitian, 16 di antaranya menerima opini going concern. Sedikitnya perusahaan yang menerima opini going concern dikarenakan perbankan merupakan lembaga yang highly regulated. Perusahaan yang mendapat opini going concern disebabkan beberapa masalah antara lain, bank yang mengalami kegagalan sistemik, masalah hukum, restrukturisasi aset, kerugian, dan perubahan kebijakan akuntansi berdampak material

Hasil analisis deskriptif aspek lingkungan pada tabel 2, menunjukkan bahwa perusahaan yang menerima opini going concern mengungkapkan lebih banyak aktivitas lingkungan dibanding yang menerima opini non going concern $(1,44>1,36)$. Namun, untuk aspek ekonomi perusahaan yang menerima opini non going concern mengungkapkan lebih banyak indikator ekonominya dibanding perusahaan yang menerima opini going concern $(1,33>1,04)$. Dalam aspek sosial perusahaan yang menerima opini going concern mengungkapkan indikator sosial lebih banyak dibanding perusahaan yang 


\section{JURNAL NOMINAL / VOLUME VI NOMOR 2 / TAHUN 2017}

menerima opini non going concern (3,75 > 3,53). Dalam variabel pertumbuhan perusahaan, baik perusahaan yang menerima opini going concern maupun non going concern sama-sama memiliki ratarata pertumbuhan negatif, dengan pertumbuhan perusahaan yan menerima opini non going concern lebih besar dari going concern $(-0,21>-0,73)$.

Dalam variable kepemilikan institusional pada tabel 1, menunjukkan nilai rata-rata $0,726>0,5$, sehingga perbankan di Indonesia dominan dimiliki olek institusi, jika dilihat pada tabel 2, perusahaan yang menerima opini going concern lebih banyak dimiliki oleh institusi dibanding perusahaan yang menerima opini non going concern $(0,86>0,79)$. Rata-rata untuk variabel Komisaris Independen dalam tabel 1 , menunjukkan nilai 0,33 (33\%), artinya bahwa perusahaan perbankan di Indonesia telah mematuhi aturan yang mensyaratkan perusahaan memiliki Komisaris Independen minimal $30 \%$ dari total dewan komisaris. Perusahaan yang menerima opini non going concern memiliki Komisaris Independen lebih besar dibanding perusahaan yang menerima opini going concern $(0,58>0,57)$. Rata-rata Komite Audit pada tabel 1 menunjukkan nilai 3,89 yang artinya telah banyak perbankan di Indonesia yang memiliki Komite Audit. Perusahaan yang menerima opini non going concern memiliki Komite Audit lebih banyak dibanding yang menerima opini going concern (3,91> $3,75)$.

\section{Hosmer and Lemeshow's Goodness of Fit}

Test

Uji Hosmer and Lemeshow's Goodness of Fit Test digunakan untuk menilai kelayakan model regresi. Berikut adalah hasil uji Hosmer and Lemeshow's:

Tabel 6. Hasil Analisis Hosmer and Lemeshow's Goodness of Fit Test

\begin{tabular}{|c|c|c|c|}
\hline \multicolumn{3}{|c|}{ Chi- } & \\
\hline Step & square & df & Sig. \\
\hline 1 & 8,149 & 8 & ,419 \\
\hline
\end{tabular}

Sumber: Data diolah (2017)

Hasil uji menunjukkan tingkat signifikansi sebesar $0,419>0,05$ yang artinya model mampu memprediksi nilai observasi dalam penelitian atau dapat dikatakan bahwa model diterima karena cocok dengan data observasinya.

\section{Menilai Kelayakan Model Regresi}

Uji ini dilakukan untuk menilai apakah model yang digunakan sesuai dengan data atau tidak. Penilaian dilakukan dengan membandingkan nilai antara -2 Loglikelihood pada awal dimana hanya dimasukkan konstantan dengan -2 Loglikelihood yang memasukkan konstanta dan variabel bebas. Berikut adalah hasil uji untuk menilai kelayakan model regersi: 
JURNAL NOMINAL / VOLUME VI NOMOR 2 / TAHUN 2017

Tabel 7. Overall Model Fit Test 1

\begin{tabular}{ccc|c}
\hline \multirow{2}{*}{ Iteration } & \multirow{2}{*}{$-2 \operatorname{LogL}$} & \multicolumn{2}{|c}{ Coefficients } \\
\cline { 3 - 4 } Step 0 & 1 & 105,258 & \multicolumn{2}{c}{ Constant } \\
\cline { 2 - 4 } & 2 & 100,807 & $-2,559$ \\
\cline { 2 - 4 } 3 & 100,698 & $-2,001$ \\
\cline { 2 - 4 } & 4 & 100,698 & $-2,087$ \\
\cline { 2 - 3 } 5 & 100,698 & $-2,087$ \\
\hline
\end{tabular}

Sumber: Data diolah (2017)

Tabel 8. Overall Model Fit Test 2

\begin{tabular}{|c|c|c|c|c|c|c|c|c|c|}
\hline \multirow[b]{2}{*}{ } & \multirow[b]{2}{*}{ 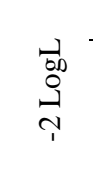 } & \multicolumn{8}{|c|}{ Coefficients } \\
\hline & & $\begin{array}{l}\vec{\Xi} \\
\text { ज्ञ } \\
\text { ठ }\end{array}$ & $\overrightarrow{|=|}$ & $\begin{array}{l}0 \\
\text { iٓ }\end{array}$ & $\begin{array}{l}0 \\
\mathscr{n}\end{array}$ & 吾 & ర్ & 晜 & 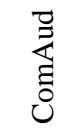 \\
\hline 1 & 96,92 & $-1,7$ &, 09 &,- 63 & ,12 &,- 01 & 1,2 &,- 72 &,- 02 \\
\hline 2 & 86,02 & $-2,9$ &, 14 & $-1,3$ & ,26 &,- 01 & 2,7 & $-1,3$ &, 02 \\
\hline 3 & 83,90 & $-4,2$ & , 12 & $-1,7$ &, 36 &,- 02 & 4,2 & $-1,4$ &, 06 \\
\hline 4 & 83,72 & $-4,9$ & , 12 & $-1,8$ &, 39 &,- 02 & 4,8 & $-1,3$ & ,09 \\
\hline 5 & 83,72 & $-4,9$ & , 12 & $-1,8$ & ,39 &,- 02 & 4,8 & $-1,3$ & ,09 \\
\hline 6 & 83,72 & $-4,9$ & , 12 & $-1,8$ & ,39 &,- 02 & 4,8 & $-1,3$ & 09 \\
\hline
\end{tabular}

Sumber: Data diolah (2017)

Nilai -2 Loglikelihood awal yang hanya memasukkan konstanta saja sebesar 100,698, sedangkan nilai -2 Loglikelihood kedua setelah memasukkan konstanta dan variabel bebas menunjukkan angka 83,72. Penurunan nilai -2 Loglikelihood menunjukkan model regresi yang baik atau dengan kata lain model yang dihipotesiskan fit dengan data.

Tabel 9. Omnnibus Tests of Model Coefficients

\begin{tabular}{llrrr}
\hline & & Chi-square & \multicolumn{1}{c}{ Df } & \multicolumn{1}{c}{ Sig. } \\
\hline \multirow{2}{*}{ Step 1 } & Step & 16,980 & 7 &, 018 \\
\cline { 2 - 5 } & Block & 16,980 & 7 &, 018 \\
\cline { 2 - 5 } & Model & 16,980 & 7 &, 018 \\
\hline
\end{tabular}

Sumber: Data diolah (2017)

Hasil uji Omnibus Tests of Model Coefficients menunjukkan nilai 0,018 yang lebih kecil dari 0,05, artinya penambahan variabel independen ke dalam model memperbaiki model fit.

\section{Koefisien Determinasi}

Besarnya nilai koefisien determinasi ditunjukkan dengan nilai Negelkerke $R$ Square. Berikut adalah hasil uji Negelkerke R Square:

Tabel 10. Negelkerke R Square Test

\begin{tabular}{|c|c|c|c|}
\hline Step & $-2 \log L$ & $\begin{array}{c}\text { Cox \& Snell } \\
\text { R Square }\end{array}$ & $\begin{array}{c}\text { Nagelkerke } \\
\text { R Square }\end{array}$ \\
\hline 1 & $83,718^{a}$ & ,111 & ,221 \\
\hline
\end{tabular}

Sumber: Data diolah (2017)

Hasil uji menunjukkan nilai Negelkerke $R$ Square sebesar 0,221 $(22,1 \%)$, yang artinya variabilitas variabel dependen yang dapat dijelaskan variabel independen adalah sebesar 22.1\%, sedangkan $83,718 \%$ dijelaskan variabel independen lain diluar penelitian.

\section{Tabel Klasifikasi}

Tabel klasifikasi menunjukkan kekuatan prediksi dari model regresi untuk memprediksi probabilitas penerimaan opini going concern. Hasil tabel klasifikasi ditampilkan dalam tabel 9.

Tabel 11. Klasifikasi

\begin{tabular}{|c|c|c|c|c|c|c|}
\hline & \multirow{3}{*}{ Observed } & & \multicolumn{4}{|c|}{ Predicted } \\
\hline & & & \multicolumn{2}{|c|}{ Going Concern } & \multirow{2}{*}{\multicolumn{2}{|c|}{$\begin{array}{c}\text { Correct } \\
(\%) \\
\end{array}$}} \\
\hline & & & 0 & 1 & & \\
\hline \multirow{2}{*}{ 竞 } & \multirow{2}{*}{ GoingConcern } & 0 & 128 & & 1 & 99,2 \\
\hline & & 1 & 14 & & 2 & 12,5 \\
\hline & \multicolumn{2}{|c|}{ Overall Percentage } & & & & 89,7 \\
\hline
\end{tabular}

Sumber: Data diolah (2017) 


\section{JURNAL NOMINAL / VOLUME VI NOMOR 2 / TAHUN 2017}

\section{Uji Multikolinearitas}

Uji multikolinartias bertujuan untuk menguji apakah dalam model regresi ditemukan adanya korelasi antar variabel independen. Berikut adalah hasil uji multikolinearitas:

Tabel 12. Uji Multikolinearitas

\begin{tabular}{lcc}
\hline \multirow{2}{*}{ Model } & \multicolumn{3}{c}{ Collinearity Statistiks } \\
\cline { 2 - 3 } & Tolerance & VIF \\
\hline Env &, 416 & 2,406 \\
\hline Eco &, 577 & 1,734 \\
\hline Soc &, 491 & 2,036 \\
\hline Growth &, 891 & 1,122 \\
\hline InsOwn &, 958 & 1,044 \\
\hline ComInd &, 788 & 1,269 \\
\hline ComAud &, 734 & 1,362 \\
\hline
\end{tabular}

Sumber: Data diolah (2017)

Dari hasil uji yang dilakukan tidak ada nilai tolerance yang kurang dari 0,10 dan tidak ada nilai VIF yang lebih dari 10 , dapat dismpulkan tidak ada multikolinearitas antar variabel independen.

\section{Model Regresi yang Terbentuk dan}

\section{Pengujian Hipotesis}

Berikut adalah hasil uji hipotesis yang dilakukan dalam penelitian ini:

Tabel 13. Pengujian Hipotesis

\begin{tabular}{|c|c|c|c|}
\hline & $\mathrm{B}$ & Sig. & Keterangan \\
\hline Env &, 116 &, 758 & Ditolak \\
\hline Eco & $-1,823$ & ,009 & Diterima \\
\hline Soc &, 390 &, 274 & Ditolak \\
\hline Growth &,- 017 &, 550 & Ditolak \\
\hline \multirow[t]{2}{*}{ InsOwn } & 4,833 &, 014 & Diterima \\
\hline & $\mathrm{B}$ & Sig. & Keterangan \\
\hline ComInd & $-1,340$ &, 656 & Ditolak \\
\hline ComAud &, 088 &, 779 & Ditolak \\
\hline Constant & $-4,939$ &, 117 & \\
\hline
\end{tabular}

Sumber: Data diolah (2017)
H1: Aspek Lingkungan Berpengaruh Negatif pada Pengungkapan Opini Going Concern

Berdasarkan uji hipotesis pada aspek lingkungan menunjukkan signifikansi sebesar 0,758 >0,05 (hipotesis ditolak), sehingga tidak terdapat pengaruh antara aspek lingkungan pada pengungkapan opini going concern. Oleh karena itu, tidak terdapat perbedaan antara perusahaan yang mengungkapkan aspek lingkungan secara penuh maupun tidak dalam pemberian opini going concern, karena antara perusahaan yang menerima opini going concern maupun non going concern sama-sama mengungkapkan aspek lingkungan. Selain itu, perbankan bukan merupakan usaha yang operasionalnya berdampak signifikan pada lingkungan, sehingga kegiatannya tidak berpengaruh signifikan pada lingkungan sebagaimana perusahaan seperti manufaktur, pertambangan,dll. Aktivitas lingkungan dalam perbankan pun masih terbatas pada kegiatan sederhana seperti pengehamatan energy, reboisasi, dan praktik green banking. Hasil uji yang dilakukan didukung penelitian Spence et al., (2012), dimana dalam penelitian Spence et al., dinyatakan bahwa tiap usaha memiliki karakteristik tersendiri, termasuk dalam aspek lingkungan, dimana terdapat usaha yang tidak berdampak signifikan pada lingkungan seperti perbankan. Oleh karena operasional perbankan tidak 


\section{JURNAL NOMINAL / VOLUME VI NOMOR 2 / TAHUN 2017}

berdampak signifikan pada perbankan, dan tidak terdapat perbedaan pengungkapan aspek lingkungan perusahaan yang menerima opini going concern dan non going concern, aspek lingkungan bukan menjadi pertimbangan auditor dalam memberi opini going concern, sehingga aspek lingkungan tidak berpengaruh pada pengungkapan opini going concern.

\section{H2: Aspek Ekonomi Berpengaruh} Negatif pada Pengungkapan Opini Going

\section{Concern}

Hasil uji hipotesis pada aspek ekonomi menunjukkan signifikansi sebesar $0,009<0,05$ (hipotesis diterima) dengan Beta -1,823. Hal tersebut menandakan bahwa terdapat pengaruh negatif antara aspek ekonomi pada pengungkapan opini going concern. Semakin banyak aktivitas dan pengungkapan aspek ekonomi maka kemungkinan pengungkapan opini going concern akan semakin kecil. Hal tersebut didukung bahwa perbankan merupakan usaha yang bergerak pada sektor ekonomi, sehingga kontribusinya akan dominan di bidang ekonomi. Selain itu, teori usaha bersama juga menyatakan bahwa dengan kontribusi ekonomi yang baik dari perusahaan, maka akan menciptakan nilai tambah untuk perusahaan. Hasil uji yang dilakukan pada aspek ekonomi didukung penelitian Chen et al., (2011), penelitian Chen et al., menyatakan bahwa kontribusi ekonomi perusahaan pada stakeholdernya akan mengurangi risiko perusahaan, hal itu karena kepercayaan stakeholder perusahaan akan semakin baik, sehingga kelangsungan usaha perusahaan pun tetap terjaga. Oleh karena itu, aspek ekonomi berpengaruh pada pengungkapan opini going concern.

\section{H3: Aspek Sosial Berpengaruh Negatif pada Pengungkapan Opini Going Concern}

Hasi uji hipotesis pada aspek sosial menunjukkan signifikansi sebesar 0,274 (hipotesis ditolak). Hal tersebut didukung bahwa antara perusahaan yang menerima opini going concern maupun non going concern sama-sama mengungkapan aspek sosial atau dengan kata lain tidak terdapat perbedaan pada pengungkapan aspek sosial perusahaan yang menerima opini going concern maupun non going concern. Terdapat perusahaan yang menerima opini going concern justru mengungkapan aspek sosial lebih banyak dibanding perusahaan yang menerima opini non going concern, begitu juga sebaliknya. Hal tersebut menyebabkan auditor tidak mempertimbangkan aspek sosial dalam memberikan opini going concern atau aspek sosial tidak berpengaruh pada pengungkapan opini going concern.

Hasil uji yang dilakukan didukung penelitian Onuorah et al., (2016). Onuorah et al., menyatakan bahwa aspek sosial tidak berpengaruh pada kelangsungan usaha perusahaan, karena aspek sosial tidak 


\section{JURNAL NOMINAL / VOLUME VI NOMOR 2 / TAHUN 2017}

berpengaruh pada kinerja keuangan perusahaan, dan bukan merupakan faktor penentu kelangsungan usaha perusahaan.

\section{H4: Pertumbuhan Perusahaan Berpengaruh Negatif pada Pengungkapan Opini Going Concern}

Hasij uji pada variabel pertumbuhan perusahaan menunjukkan signifikansi sebesar 0,550>0,05 (hipotesis ditolak). Hal tersebut didukung bahwa baik perusahaan yang menerima opini going concern maupun non going concern sama-sama memiliki rata-rata pertumbuhan negatif, yang menandakan pertumbuhan perusahaan bukan satu-satunya tolak ukur dalam memberi opini going concern. Perusahaan dengan pertumbuhan positif tidak menjamin mendapat opini non going concern, sebaliknya tidak selalu perusahaan dengan pertumbuhan negatif mendapatkan opini going concern. Seorang auditor melihat lebih jauh selain sisi pertumbuhan perusahaan, ketika pertumbuhan perusahaan negatif namun saldo laba dan total ekuitasnya masih support, maka auditor berkeyakinan bahwa kelangsungan usaha perusahaan masih baik, sebaliknya meskipun pertumbuhan perusahaan positif namun saldo laba dan total ekuitasnya negatif, auditor cenderung ragu atas kemampuan kelangsungan usaha perusahaan. Hasil uji ini didukung oleh penelitian Setyarno et al., (2006), Santosa dan Wedari (2007), Sutedja (2010),
Rudyawan dan Badera (2009), serta Yunida dan Wardana (2013).

H5: Kepemilikan Institusional Berpengaruh Negatif pada

\section{Pengungkapan Opini Going Concern}

Hasil uji yang dilakukan pada variabel kepemilikan institusional menunjukkan signifikansi sebesar 0,014 dengan Beta 4,833, artinya terdapat pengaruh positif antara kepemilikan institusional dengan pengungkapan opini going concern, semakin besar kepemilikan institusional maka kemungkinan pengungkapan opini going concern akan semakin besar pula. Hal itu didukung bahwa perusahaan yang menerima opini going concern memiliki kepemilikan institusional lebih besar dibandingkan dengan perusahaan yang menerima opini non going concern. Bila dikaji lebih lanjut, institusi yang memiliki perbankan yang mendapat opini going concern masih memiliki hubungan yang dekat dengan perbankan, layaknya hubungan antara induk dan anak perusahaan. Hasil uji yang dilakukan didukung oleh penelitian Cornett et al., (2007), dimana Cornett et al., menyatakan bahwa kepemilikan institusional tidak berdampak pada perusahaan, hal itu karena pemilik institusional jarang berada di dewan perusahaan, sehingga mereka tidak bisa mengawasi jalannya perusahaan dengan efektif dan efisien, selain itu kepemilikan 


\section{JURNAL NOMINAL / VOLUME VI NOMOR 2 / TAHUN 2017}

institusional yang besar akan cenderung mengarah ke konflik kepentingan (Curtis, 2017) terlebih bagi pemilik institusi yang masih memiliki hubungan dekat dengan perusahaan. Oleh karena itu, kepemilikan institusional berpengaruh pada pengungkapan opini going concern.

\section{H6: Komisaris Independen Berpengaruh} Negatif pada Pengungkapan Opini Going

Concern

Hasil uji yang dilakukan pada variabel Komisaris Independen menunjukkan signifikansi sebesar 0,656 (hipotesis ditolak). Hal tersebut didukung dengan hasil analisis deskriptif pada perusahaan yang menerima opini going concern dan non going concern dimana keduanya memiliki proporsi Komisaris Independen yang sama yaitu 0,6 (60\%) dari total dewan komisaris dan rata-rata keseluruhan yang menunjukkan nilai 0,33 (33\%) dalam Komisaris Independen. Teori agensi menyatakan bahwa permasalahan muncul karena ada perbedaan manajemen dan stakeholder, sehingga diperlukan pihak independen yaitu Komisaris Independen dalam menengahinya. Keberadaan Komisaris Independen penting untuk mengawasi perusahaan, sehingga setiap perusahaan yang listing di BEI baik yang menerima opini going concern maupun non going concern sama-sama menaati aturan Kep 361/BEJ/06-2000 yang mewajibkan perusahaan setiap perusahaan yang listing di BEI memiliki Komisaris Independen minimal $30 \%$ dari total dewan komisaris. Hal tersebut menandakan tidak ada perbedaan antara perusahaan yang menerima opini going concern maupun non going concern dalam kepemilikan Komisaris Independen di mata auditor karena sifat Komisaris Independen yang wajib dimiliki oleh tiap perusahaan. Hasil uji yang dilakukan didukung penelitian Adjani dan Rahardja (2013), Linoputri (20), dan Iskandar et al., (2011)

H7: Komite Audit Berpengaruh Negatif pada Pengungkapan Opini Going Concern

Hasil uji pada variabel Komite Audit menunjukkan signifikansi sebesar 0,779 > 0,05 (hipotesis ditolak). Dari hasil tersebut dapat dikatakan bahwa ukuran Komite Audit kurang menunjang efektifitas kinerja Komite Audit, posisi Komite Audit hanya sebatas untuk memenuhi persyaratan pencatatan di bursa. Hasil penelitian juga menunjukkan kurang dipahaminya prinsip good corporate governce oleh pelaku bisnis serta kurangnya peran Komite Audit dalam menegakkan prinsip-prinsip good corporate governance didukung oleh survei GCG oleh CLSA Asian Pacific Market 2016 yang menempatkan Indonesia di urutan terbawah dalam penerapan prinsip good corporate governance. Hasil uji yang dilakukan didukung oleh penelitian 


\section{JURNAL NOMINAL / VOLUME VI NOMOR 2 / TAHUN 2017}

Sihombing et al., (2014) dan Linoputri (2010).

\section{KESIMPULAN DAN SARAN}

\section{Kesimpulan}

Pengungkapan opini going concern dapat dipengaruhi oleh beberapa hal. Dari hasil penelitian, ditemukan bahwa aspek ekonomi dan kepemilikan institusional berpengaruh pada pengungkapan opini going concern pada perusahaan perbankan yang terdaftar di BEI tahun 2011 - 2015, sedangkan aspek lingkungan, aspek sosial, pertumbuhan perusahaan, Komisaris Independen, dan Komite Audit tidak berpengaruh pada pengukapan opini going concern.

\section{Keterbatasan}

Keterbatasan penelitian ini terletak pada pengambilan sampel perusahaan (29 dari 44 perusahaan), tahun sampel (2011 2015), proksi yang digunakan untuk variabel Komisaris Independen dan Komite Audit hanya terbatas pada keberadaanya di perusahaan, variabel aspek lingkungan bukan merupakan kegiatan yang signifikan pada perbankan, serta variabel dependen yang dijelaskan oleh variabel indpeenden dalam penelitian ini sebesar 22,1\%, sehingga masih terdapat $83,718 \%$ variabilitas variabel independen yang belum dijelaskan dalam penelitian ini.

\section{Saran}

Penelitian diharapkan mampu menjadi sebuah acuan untuk auditor dan perusahaan dalam memahami opini going concern, terutama faktor yang mempengaruhinya, sehingga untuk auditor dapat meminimalisir kesalahan dalam pengungkapan kelangsungan usaha perusahaan dan pemberian opini going concern, serta untuk perusahaan dapat menjalankan perusahaan dengan baik, menjaga kelangsungan usaha, dan terhindar dari masalah going concern.

Penelitian selanjutnya diharapkan mampu memberi nilai lebih pada penelitian mengenai going concern ini, seperti penembahan variabel independen, penggunaan data primer, serta perluasan pengambilan sampel dan tahun sampel.

\section{DAFTAR PUSTAKA}

Adjani, E. D., \& Rahardja, S. (2013).Analisis Pengaruh Good Corporate Governance terhadap Kemungkinan Pemberian Opini Audit Going Concern. Diponegoro Journal of Accounting.

BAPEPAM-LK. (2004). Keputusan Ketua BAPEPAM No. Kep-29/PM.

BAPEPAM-LK. (2016, 12 23). Peraturan Bapepam-LK nomer X.K.6. Retrieved from:http://www.bapepam.go.id/old/h ukum/peraturan/X/X.K.6.pdf

Chen, L., Srinidhi, B., Tsang, A., \& Yu, W. (2011). How Do Auditors Respond to Corporate Social Responsibility Performance?

Cornett , M. M., Marcus, A. J., Saunders, A., \& Tehranian, H. (2007). The Impact 


\section{JURNAL NOMINAL / VOLUME VI NOMOR 2 / TAHUN 2017}

of Institutional Ownership on Coperate Operating Performance. Journal of Banking and Finance.

Curtis, G. (2017, 3 3). Investopedia.com. Retrieved from The Pros And Cons Of Institutional Ownership: http://www.investopedia.com/articles/ stocks/07/insitutional-owners.asp

Ghozali, I. (2011). Aplikasi Analisis Multivariate dengan Program IBM SPSS 19. Semarang: Penerbit Universitas Diponegoro.

GRI. (2011). Sustainability Reporting Guidelines. Global Reporting Initiative.

Linoputri, F. P. (2010). Pengaruh Corporate Governance terhadap Penerimaan Opini Audit Going Concern. Skripsi.

Onuorah, Chi-Chi, A., \& Friday, I. O. (2016). Corporate Social Responsibility and its Impact on Firms' Going Concern in Nigeria. Imperial Journal of Interdisciplinary Research.

Peraturan, P. R. (2016, 12 22). UndangUndang Republik Indonesia nomer 40 tahun 2007 tentang Perseroan Terbatas. Retrieved from http://prokum.esdm.go.id/uu/2007/uu40-2007.pdf

Petronila, T. A. (2004). Pertimbangan Going Concern Perusahaan dalam Pemberian Opini Audit. Jurnal Balance.

Porter, M. E., \& Kramer, M. R. (2006). Strategy and Society: the link between competitive advantage and corporate social responsibility. Harvard Business Review.

Rudyawan , A. P., \& Badera, I. N. (2009). Opini Audit Going Concern: Kajian Berdasarkan Model Prediksi Kebangkrutan, Pertumbuhan Perusahaan, Leverage dan Reputasi Auditor. Jurnal Ilmiah Akuntansi dan Bisnis.

Santosa, A. F., \& Wedari, L. K. (2007). Analisis Faktor-Faktor yang mempengaruhi Kecenderungan Penerimaan Opini Audit Going Concern. JAAI.

Setyarno, E. B., \& Januarti, I. (2006). Pengaruh Kualitas Audit, Kondisi Keuangan Perusahaan, Opini Audit Tahun Sebelumnya, Pertumbuhan Perusahaan terhadap Opini Audit Going Concern. Simposium Nasional Akuntansi 9. Padang.

Sihombing, N. F. (2014). Dampak Mekanisme Good Corporate Governance terhadap Penerimaan Opini Audit Going Concern. Prosiding - Simposium Riset Ekonomi.

Spence, L. J., Agyemang, G., \& Rinaldi, L. (2012). Environmental Aspects of Sustainability: SMEs and The Role of Accountant. ACCA Research.

Sutedja, C. (2010). Faktor Faktor Yang Berpengaruh Terhadap Pemberian Opini Audit Going Concern Pada Perusahaan Manufaktur.

Yunida, R., \& Wardana, M. W. (2013). Pengaruh Kualitas Audit, Kondisi Keuangan Perusahaan, Opini Audit Tahun Sebelumnya, Pertumbuhan Perusahaan terhadap Opini Audit Going Concern. INTEKNA. 